\title{
Addendum to the Program for the 2010 Mid-Year Meeting:
}

Page 27: P. MARIA, M. MOSKALA, J. POLAK, I. HERMAN-SUCHARSKA \& A. GIBEK. Cerebral plasticity in children with post-traumatic aphasia, based on data from functional magnetic resonance (fMRI).

First Author should be M Pachalska

Page 60: E. SITEK \& A. XX. Frontotemporal Dementia and Parkinsonism Linked to Chromosome 17 - the First Polish Family.

Authors for abstract should be listed as: E Sitek, E Narożańska, W Kucharska, P Robowski, B Brockhuis, P Lass, M Dubaniewicz, D Wieczorek, M Schinwelski, A Roszmann, M Baker, B Jasińska-Myga, R Rademakers, Z Wszołek, J Sławek 